\title{
Production of probiotic fresh white cheese using co-culture with Streptococcus thermophilus
}

\author{
Oktay YERLIKAYA ${ }^{1}$, Elif OZER ${ }^{1 *}$
}

\begin{abstract}
In this research, the probiotic Streptococcus thermophilus was inoculated into milk as co-culture to produce probiotic cheese. The effects of using Streptococcus thermophilus with other probiotic bacteria on cheese composition, and microbiological viability during 28 days of storage were investigated. Sensorial properties were determined only at $1^{\text {st }}$ and $28^{\text {th }}$ days of storage. The results showed that the use of Streptococcus thermophilus as co-culture in probiotic cheese production did not affect negatively the cheese components. Fat and dry matter properties of cheese weren't influenced by added probiotic bacteria. However, different level of $\mathrm{pH}$, salt and lactic acid were detected. All probiotic bacteria were present in high levels throughout storage of cheeses, above 7 Log cfu.g ${ }^{-1}$, threshold required for probiotic activity. Sensory panel showed that the highest average sensory evaluation points were recorded in cheeses made with Streptococcus thermophilus plus Lactobacillus casei, whereas other probiotic bacteria combinations had been affected less in regard to taste or appearance.
\end{abstract}

Keywords: probiotic cheese; Streptococcus thermophilus; fresh white cheese; cheese starter; probiotic bacteria.

\section{Introduction}

It is difficult to separate functional and conventional foods in appearance. Contrary to conventional foods, functional foods have evidenced physiological benefits. In addition to basic nutritional functions e. g. gut health, they show physiological benefits and can reduce the risk of chronic disease. Functional food can provide the needs of the body with the required amount of vitamins, fats, proteins, carbonhydrates, etc., needed for its healthy survival (Food and Agriculture Organization of the United Nations, 2007; Cencic \& Chingwaru, 2010).

Probiotics are the most commonly used dietary method of influencing the gut flora composition. A recent definition of probiotics was given as 'a live microbial feed supplement that is beneficial to health (Gibson, 2007). Probiotics are usually used in dairy products. As well as cheese is a good vehicle for these microorganisms. Besides the viability of probiotics in cheese, it is important that incorporation of probiotic bacteria should not affect the expected sensory characteristics (flavor, texture, and appearance) of conventional (non-probiotic) cheeses. Although several studies have shown probiotic cultures didn't considerably affect the sensory quality of cheese, it is thought that their addition might contribute to different flavor and texture characteristic (Karimi et al., 2012a, b).

Some probiotic mixed cultures, e.g. ABT cultures (containing Lactobacillus acidophilus, Bifidobacterium and Streptococcus thermophilus) have been developed to bring out the preferred flavors in the products in which they are used. The introduction of cultures for direct inoculation of the cheese vat, "direct vat set" (DVS), has allowed culture producers to launch new culture blends, consisting of both thermophilic (mainly S. thermophilus) and mesophilic strains (Buriti et al., 2007a).
Turkish Beyaz cheese is one of the Turkish cheeses which has a economic value (Hayaloglu et al., 2002). It is a soft or semi-hard type cheese which is manufactured from sheep's or cow's milk or their mixture without heat treatment and ripened in brine (Oner et al., 2006). Cheese manufacturing began in ancient times with the practice of transporting milk in animal stomachs and bladders. Over the centuries, cheese making has been modified and refined. Today, at least 800 different types of cheeses have been identified worldwide. Many cheese varieties which are known only in a restricted geographic area in the world are produced and consumed locally in small quantities. There are more than 50 varieties of cheese in Turkey; however, three of them (Beyaz, Kasar and Tulum cheeses) are the most popular cheeses (Hayaloglu et al., 2007; Cakmakci et al., 2008; Tuncer, 2009).

In recent years cheese is very popular subject of various marketing and research studies. Because it is a good alternative for delivery of probiotics into the intestine. Fermented milks have long been used as the main vehicles for probiotic strains. The supplementation of cheeses with probiotic bacteria represents the aggregation of added value to a product that already has benefits inherent in its composition (Gomes et al., 2011; Minervini et al., 2012). The ingestion of cheese supplemented with probiotic bacteria has been associated with a variety of benefits to human health, such as improvements in the immune system, improvements in oral and intestinal health in the elderly and reinforcement of intestinal immuniy (Lollo et al., 2012; Albenzio et al., 2013a, b). Cheese has certain advantages as a carrier of probiotics compared with more acidic fermented dairy products such as yogurt. It creates a buffer against the high acidic environment in the gastrointestinal tract (GIT) and thus creates a more available environment for probiotic survival throughout 
gastric transit (Karimi et al., 2012a, b; Ortakci et al., 2012). As already reported by several authors, cheese is a promising food matrix for probiotics. But, strain selection and possible process regulations should be carefully evaluated to maximize probiotic cell viability during cheese manufacture and storage, as well as to limit possible changes in organoleptic properties. It could be said that only a few probiotic cheeses have been successfully developed for the market when compared with yoghurts or fermented milks because of product quality that can be affected by the addition of some probiotic bacteria (Grattepanche et al., 2008).

In this research, the probiotic Streptococcus thermophilus was inoculated into milk as co-culture to produce probiotic cheese. The effects of using Streptococcus thermophilus with other probiotic bacteria on cheese composition, and microbiological viability during 28 days of storage were investigated. Sensorial properties were determined only at $1^{\text {st }}$ and $28^{\text {th }}$ days of storage.

\section{Materials and methods}

Raw cow's milk supplied from Ege University, Menemen Practise and Research Farm in Faculty of Agriculture (Izmir, Turkey). Rennet was obtained from Mayasan Gida Sanayi ve Ticaret A.S. (Yenibosna, Istanbul, Turkey) and used to coagulate milk in liquid form (coagulating power 1:10000). Calcium chloride was provided commercially from Horasan Kimya (Ankara). Probiotic starter cultures were obtained from DSM Food Specialties, Chr. Hansen and CSL Food Company.

In this research, four groups of white cheeses were manufactured. Four cheese-making trials were prepared using different probiotic bacteria; PT (Streptococcus thermophilus + Lactobacillus plantarum), RT (Streptococcus thermophilus + Lactobacillus rhamnosus), ST (Streptococcus thermophilus + Lactobacillus acidophilus), and CT (Streptococcus thermophilus + Lactobacillus casei). Laboratory-scale cheese making trials were performed initially with $135 \mathrm{~L}$ of raw milk. The milk was pasteurized at $82{ }^{\circ} \mathrm{C}$ for two min and cooled to $37^{\circ} \mathrm{C}$. Then it was divided into four equal parts. A solution of 20 g. $100 \mathrm{~L}^{-1} \mathrm{CaCl}_{2}$ was added to each batch. Then, one of the four culture mixes as described above was introduced into each vat rate of $0.5 \mathrm{ml} .100 \mathrm{ml}^{-1}$ and fermentation had been begun. Fermentation of cheeses was continued until the $\mathrm{pH}$ was increased to 6.1-6.2 which is required $\mathrm{pH}$ for the production of white cheese. A 120 milli liter of chymosin (Peyma Hansen, Turkey) dispersed in $900 \mathrm{~mL}$ water was added into each vat to coagulate the milk in $90 \mathrm{~min}$. After coagulation, the curds were cut into small cubes $\left(1 \mathrm{~cm}^{3}\right)$ and allowed to rest in the whey for 10-15 min. Then the surfaces of the curds were covered with cheese cloth, drained without pressure for $\sim 30 \mathrm{~min}$, and pressed for $90 \mathrm{~min}$. When the curd reached the appropriate strength, the cheese cloths were opened and the cheeses were cut into cubes about $7 \times 7 \times 7 \mathrm{~cm}^{3}$ with weights of 400-500 g. The cubes were brine-salted $\left(10 \mathrm{~g} 100 . \mathrm{g}^{-1} \mathrm{NaCl}\right)$ for three hours. After brine-salting, cheeses were held at room temperature for $12 \mathrm{~h}$. The brined cheeses blocks were then packed with vacuum packaging technique. After packaging, all cheese batches were storaged at $4{ }^{\circ} \mathrm{C}$ for 28 days in cold room. The manufacture of cheese was performed in triplicate.

\subsection{Physicochemical analysis}

Samples were taken from all experimental cheese batches at weekly intervals during 28 days of storage and analyzed in duplicate for $\mathrm{pH}$ and lactic acid \% whereas fat, dry matter and salt content were determined for only first day of storage according to the Turkish Standard (2006). The $\mathrm{pH}$ of the samples was measured with a $\mathrm{pH}$-meter (Hanna 211, Portugal).

\subsection{Microbiological analysis}

Viability of probiotic bacteria was assessed during storage period of 28 days at $4{ }^{\circ} \mathrm{C}$. Ten grams of cheese were homogenized with $90 \mathrm{~mL}$ of sterile pepton water $0.1 \mathrm{~g} 100 \mathrm{ml}^{-1}$ with stomacker. Decimal dilutions in pepton water were made and plated on LPSM (L. plantarum selective medium) for L. plantarum, MRSVancomycin for L. rhamnosus, MRS-Sorbitol for L. acidophilus, MRS-Vancomycin for L. casei, and M17-lactose agar for S. thermophilus (Merck, Germany) for the probiotic culture counts (Jordano et al., 1992; Tharmaraj \& Shah, 2003; Dave and Shah, 2006; Bujalance et al., 2006; Tabasco et al., 2007). While MRS plates were incubated in anerobic conditions for $48 \mathrm{~h}$ at $37^{\circ} \mathrm{C}$, M17 plates were incubated in aerobic conditions for $48 \mathrm{~h}$ at $37^{\circ} \mathrm{C}$. Yeast Extract Glucose Chloramphenicol Agar (Merck, Germany) was used to determine yeasts and moulds (Ethiopian Standard Agency, 2012). Total coliform bacteria were detected by using Leuryl Sulphate Tryptose Broth (Merck, Germany) with most probably count technique (International Organization for Standardization, 2000).

\subsection{Sensorial analysis}

Sensorial properties were determined only at 1st and 28 th days of storage because of not monitored ripening in cheese. Evaluation was based on four features aroma, texture, and general acceptability fourteenth day of storage resulting in a maximum of nine points for each characteristic. The acceptability test was carried out with 7 trained panelists familiar with the product. A 9-point hedonic scale was used to evaluate the acceptability of the products including both the number and verbal scores were provided to the panelists. The scores were; like extremely (9), like very much (8), like moderately (5), neither like nor dislike (4), dislike moderately (3), dislike very much (2), dislike extremely (1). A section for the panelist's comments was present in the evaluation sheet (Kahraman \& Ustunol, 2012).

\subsection{Statistical analysis}

Statistical analysis of the datas was done using the analysis of variance in SPSSv.10.05 (SPSS, Chicago, Illinois, USA). Means with a significant difference were compared by Duncan's multiple range tests. P-values $<0.05$ were considered statistically significant. All analyses were performed in duplicate.

\section{Results and discussion}

The average composition characteristics of raw cow's milk used in making cheese were, $8.59 \pm 0.18 \mathrm{~g} 100 \mathrm{ml}^{-1}$ non-fat total solids, $3.68 \pm 0.13100 \mathrm{ml}^{-1}$ fat, $3.55 \pm 0.15100 \mathrm{ml}^{-1}$ lactose, $3.24 \pm 0.06100 \mathrm{ml}^{-1}$ total protein and $0.135 \pm 0.00100 \mathrm{ml}^{-1}$ 
acidity as lactic acid (Table 1). Results were in agreement with Turkish Food Codex Communiqué No 2000/6 on Raw Milk and Heat Treated Drinking Milk Regulation (Turkey, 2000).

\subsection{Physico-chemical properties of probiotic cheeses}

Some physic-chemical properties of probiotic cheese were given in Table 2. The results showed that the use of $S$. thermophilus as co-culture in probiotic cheese production did not affect negatively the cheese components. Fat and dry matter properties of cheese weren't influenced by added probiotic bacteria. However, different level of $\mathrm{pH}$, salt and lactic acid were detected.

The highest dry matter content was determined for RT sample, PT, AT and CT samples followed this, respectively. Between samples while for PT, RT and AT very closed dry matter contents were determined, for CT a lower dry matter was observed $(\mathrm{P}<0.05)$. This condition may be also varied due to the curd processing technique, the rate and amount of pressure, culture activity. Regarding to the fat contents of the samples, it was seen that a significant difference wasn't determined, PT, RT and AT samples were equal, for CT samples 0.25 more fat

Table 1. Chemical composition and acidity of raw cow's milk used for production of probiotic cheese.

\begin{tabular}{lc}
\hline \multicolumn{1}{c}{ Composition } & Raw Cow's Milk \\
\hline Nonfat total solids (\%) & $8.59 \pm 0.18$ \\
Fat (\%) & $3.68 \pm 0.13$ \\
Lactose (\%) & $3.55 \pm 0.15$ \\
Protein (\%) & $3.24 \pm 0.06$ \\
Acidity (Lactic acid \%) & $0.135 \pm 0.00$ \\
pH & $6.85 \pm 0.10$ \\
\hline
\end{tabular}

Table 2. Some chemical properties of probiotic cheese.

\begin{tabular}{cccc}
\hline Sample No & Dry matter (\%) & Fat (\%) & Salt (\%) \\
\hline PT & $49.11 \pm 0.17^{\mathrm{a}}$ & $25.50 \pm 0.70$ & $5.03 \pm 0.10$ \\
RT & $49.32 \pm 0.07^{\mathrm{a}}$ & $25.50 \pm 0.70$ & $5.07 \pm 0.08$ \\
AT & $49.01 \pm 0.32^{\mathrm{a}}$ & $25.50 \pm 0.70$ & $4.93 \pm 0.07$ \\
CT & $48.63 \pm 0.09^{\mathrm{b}}$ & $25.75 \pm 0.35$ & $4.91 \pm 0.05$ \\
\hline
\end{tabular}

PT (Streptococcus thermophilus + Lactobacillus plantarum). RT (Streptococcus thermophilus + Lactobacillus rhamnosus). AT (Streptococcus thermophilus + Lactobacillus acidophilus). CT (Streptococcus thermophilus + Lactobacillus casei). observed was seen $(\mathrm{P}>0.05)$. Salt contents were varied 4.91 and $5.07 \%$, the difference between the samples were found insignificant statistically $(\mathrm{P}>0.05)$. For the salt contents of the samples occurred slight differences are related to the brine level was taken by the curd, dry matter and curd processing techniques as used starter culture.

$\mathrm{pH}$ and acidity properties of probiotic cheese during storage were given Table 3. According to Table 3, it was seen that the $\mathrm{pH}$ of all the samples has decreased. When consideration was made between the samples, beginning the storage while the highest $\mathrm{pH}$ was determined for CT, the lowest was determined for PT. Between the samples reduction different $\mathrm{pH}$ levels is derived from the activity of starter probiotics which were present in the culture and the differences the levels of the forming lactic acid. In the same manner as for $\mathrm{pH}, \%$ amount of lactic acid and the differences between the samples were occurred $(\mathrm{P}<0.05)$. During storage depending on the activity of culture bacteria different amounts of lactic acid formation creates this situation. Especially for CT high lactic acid amount attracts notice.

Differences in $\mathrm{pH}$ may help to explain different rheological properties showed by some cheeses during compression. The maximum level of casein hydration occurs in $\mathrm{pH}$ values around 5.2 (Buriti et al., 2007a). Magdoub et al. (2005) reported that the decrease in $\mathrm{pH}$ values may be due to the convert to residual lactose in cheese to lactic acid and free fatty acid which had developed in the cheese. Fooks et al. (1999) reported that the decrease in $\mathrm{pH}$ values may be due to short chain fatty acids which produced in varying quantities as metabolic end product of the probiotic bacteria. Buriti et al. (2007a) determined that $\mathrm{pH}$ decreasing capacity of $S$. thermophilus he had used in the production of Minas fresh cheese is high and during production for all cheese samples $\mathrm{pH}$ has decreased. Basyigit Kilic et al. (2009) showed that the chemical analysis of probiotic cheese samples utilization of the tested probiotic microorganisms in Turkish Beyaz cheese production has no adverse effect on cheese composition. The results obtained in this study are in agreement with the results of researchers concerned.

\subsection{Probiotic viability of probiotic white cheeses}

However, although cheese is likely one of the best carriers for probiotics, the addition of high numbers of viable and metabolically active cells can affect product quality, especially

Table 3. $\mathrm{pH}$ and acidity properties of probiotic cheese during storage.

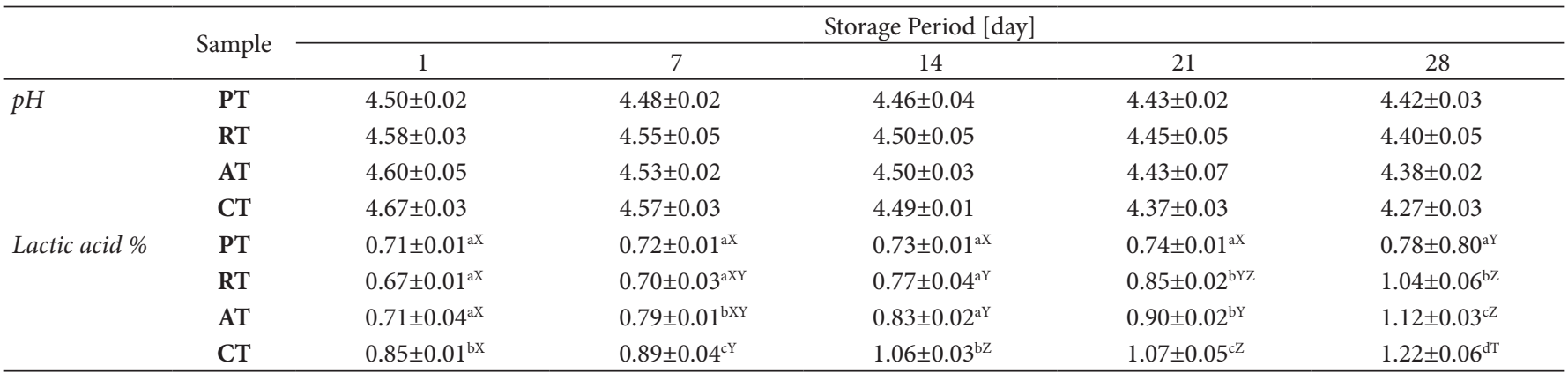


organoleptic properties (Grattepanche et al., 2008). Probiotic viability of probiotic white cheese samples during storage was given Table 4 . The viability of $S$. thermophilus of the samples was determined different from each other and this differences were identified statically significant $(\mathrm{P}<0.05)$. For $\mathrm{PT}$ and $\mathrm{RT}$ samples S. thermophilus viability increased during storage, for AT sample decreased was recorded. Besides for CT sample in terms of $S$. thermophilus viability no significant difference was detected $(\mathrm{P}>0.05)$. In the production of probiotic white cheeses the number of probiotic bacteria used in addition to $S$. thermophilus, while for PT (L. plantarum) and RT (L. rhamnosus) increase occurred, for AT sample reduction occurred $(\mathrm{P}<0.05)$. For CT (L. casei) sample significant increase or decrease wasn't occurred. This situation can be explained decrease the viability of the species which are sensitive increases in acidity as $L$. acidophilus.

All probiotic bacteria were present in high levels throughout storage of cheeses, above 6-7 $\log$ cfu. $\mathrm{g}^{-1}$, threshold required for probiotic activity. Stanton et al. (1998) reported that $L$. paracasei was also satisfactorily viable during the long ripening period of Cheddar cheese. Vinderola et al. (2000) evaluated the suitability of Argentinian Fresco cheese as a food carrier of probiotic cultures. We used cultures of Bifidobacterium bifidum, Bifidobacterium longum, Bifidobacterium ssp., Lactobacillus acidophilus, and Lactobacillus casei in different combinations, as probiotic adjuncts. The results had showed that nine different combinations of bifidobacteria and $L$. acidophilus had a satisfactory viability (count decreases in $60 \mathrm{~d}<1 \log$ order) in the cheese. Both combinations of bifidobacteria and $L$. casei cultures assayed also showed a satisfactory survival (counts decreased $<1 \log$ order for bifidobacteria but no decrease was detected for L. casei). Buriti et al. (2007a) tested the addition of $L$. paracasei subsp. paracasei LBC 82 in coculture with $S$. thermophilus to potentially probiotic and synbiotic fresh cream cheeses (without and with inulin, respectively). Viable counts of $L$. paracasei remained above $7 \mathrm{Log}$ cfu.g ${ }^{-1}$ during the entire storage period, 21 days, for both cheeses. In another study, Buriti et al. (2007b) observed the viability of $L$. acidophilus La-5 and B. animalis subsp. lactis Bb-12 added to Minas fresh cheese. Both probiotic cultures were present in high levels throughout storage, above 6 Log.cfu ${ }^{-1}$ and resulted in cheeses with texture comparable to the traditional ones and with favourable sensorial features (Gomes da Cruz et al., 2009). Ortakci et al. (2012) investigated the survival of the probiotic Lactobacillus paracasei during the manufacture and storage of low-moisture part-skim Mozzarella

Table 4. Viability of probiotic bacteria of cheese during storage period.

\begin{tabular}{|c|c|c|c|c|c|c|}
\hline & \multirow{2}{*}{ Sample } & \multicolumn{5}{|c|}{ Storage Period (day) } \\
\hline & & 1 & 7 & 14 & 21 & 28 \\
\hline \multirow{4}{*}{$\begin{array}{l}\text { S. thermophilus } \\
\left(\operatorname{Log~cfu.g~}^{-1}\right)\end{array}$} & PT & $9.01 \pm 0.04^{\mathrm{bB}}$ & $8.94 \pm 0.11^{\mathrm{cB}}$ & $9.01 \pm 0.07^{\mathrm{bB}}$ & $9.28 \pm 0.01^{\mathrm{bB}}$ & $9.73 \pm 0.03^{\mathrm{bA}}$ \\
\hline & RT & $8.74 \pm 0.04^{\mathrm{bB}}$ & $8.64 \pm 0.04^{\mathrm{cB}}$ & $8.89 \pm 0.03^{\mathrm{bAB}}$ & $9.08 \pm 0.05^{\mathrm{bA}}$ & $9.49 \pm 0.10^{\mathrm{bA}}$ \\
\hline & AT & $10.28 \pm 0.06^{\mathrm{aA}}$ & $9.24 \pm 0.34^{\mathrm{bB}}$ & $9.31 \pm 0.15^{\mathrm{bB}}$ & $9.30 \pm 0.09^{\mathrm{bB}}$ & $9.44 \pm 0.03^{\mathrm{bB}}$ \\
\hline & CT & $10.15 \pm 0.05^{\mathrm{a}}$ & $10.23 \pm 0.03^{\mathrm{a}}$ & $10.20 \pm 0.01^{\mathrm{a}}$ & $10.13 \pm 0.02^{\mathrm{a}}$ & $10.07 \pm 0.01^{\mathrm{a}}$ \\
\hline \multirow{4}{*}{$\begin{array}{l}\text { L. plantarum } \\
\left(\text { Log cfu.g }^{-1}\right)\end{array}$} & PT & $7.51 \pm 0.38^{\mathrm{B}}$ & $7.16 \pm 0.17^{\mathrm{C}}$ & $7.84 \pm 0.02^{\mathrm{B}}$ & $7.94 \pm 0.02^{\mathrm{B}}$ & $8.89 \pm 0.03^{\mathrm{A}}$ \\
\hline & RT & - & - & - & - & - \\
\hline & AT & - & - & - & - & - \\
\hline & CT & - & - & - & - & - \\
\hline \multirow{4}{*}{$\begin{array}{l}\text { L. rhamnosus } \\
\left(\mathrm{Log} \mathrm{cfu.g}^{-1}\right)\end{array}$} & PT & - & - & - & - & - \\
\hline & RT & $8.21 \pm 0.02^{\mathrm{C}}$ & $9.37 \pm 0.07^{\mathrm{A}}$ & $8.76 \pm 0.03^{\mathrm{B}}$ & $8.06 \pm 0.03^{\mathrm{C}}$ & $8.24 \pm 0.03^{\mathrm{C}}$ \\
\hline & AT & - & - & - & - & - \\
\hline & CT & - & - & - & - & - \\
\hline \multirow{4}{*}{$\begin{array}{l}\text { L. acidophilus } \\
\left(\text { Log cfu.g }^{-1}\right)\end{array}$} & PT & - & - & - & - & - \\
\hline & RT & - & - & - & - & - \\
\hline & AT & $10.23 \pm 0.06^{\mathrm{A}}$ & $8.15 \pm 0.15^{\text {В }}$ & $7.76 \pm 0.02^{\mathrm{C}}$ & $7.62 \pm 0.01^{\mathrm{C}}$ & $7.42 \pm 0.06^{\mathrm{C}}$ \\
\hline & CT & - & - & - & - & - \\
\hline \multirow{4}{*}{$\begin{array}{l}\text { L. casei } \\
\left(\text { Log cfu.g }^{-1}\right)\end{array}$} & PT & - & - & - & - & - \\
\hline & RT & - & - & - & - & - \\
\hline & AT & - & - & - & - & - \\
\hline & CT & $9.12 \pm 0.03^{\mathrm{A}}$ & $9.16 \pm 0.06^{\mathrm{A}}$ & $9.24 \pm 0.05^{\mathrm{A}}$ & $9.25 \pm 0.03^{\mathrm{A}}$ & $9.08 \pm 0.08^{\mathrm{A}}$ \\
\hline \multirow{4}{*}{$\begin{array}{l}\text { Yeast and Moulds } \\
\left(\mathrm{Log} \mathrm{cfu.g}^{-1}\right)\end{array}$} & PT & $<10$ & $<10$ & $<10$ & $<10$ & $<10$ \\
\hline & RT & $<10$ & $<10$ & $<10$ & $<10$ & $<10$ \\
\hline & AT & $<10$ & $<10$ & $<10$ & $<10$ & $<10$ \\
\hline & CT & $<10$ & $<10$ & $<10$ & $<10$ & $<10$ \\
\hline \multirow{4}{*}{$\begin{array}{l}\text { Total Coliform } \\
\text { Bacteria } \\
\left(\text { EMS g }^{-1}\right)\end{array}$} & PT & $<3$ & $<3$ & $<3$ & $<3$ & $<3$ \\
\hline & RT & $<3$ & $<3$ & $<3$ & $<3$ & $<3$ \\
\hline & AT & $<3$ & $<3$ & $<3$ & $<3$ & $<3$ \\
\hline & CT & $<3$ & $<3$ & $<3$ & $<3$ & $<3$ \\
\hline
\end{tabular}

PT (Streptococcus thermophilus + Lactobacillus plantarum). RT (Streptococcus thermophilus + Lactobacillus rhamnosus). AT (Streptococcus thermophilus + Lactobacillus acidophilus). CT (Streptococcus thermophilus + Lactobacillus casei). 
Table 5. Sensorial properties of probiotic cheese $1^{\text {st }}$ and $28^{\text {th }}$ days of storage.

\begin{tabular}{ccccc}
\hline Storage Period (Days) & Sample No & Texture (1-9 point) & Taste and Aroma (1-9 point) & Ovaral Acceptance (1-9 point) \\
\hline $\mathbf{1}$ & PT & $6.6 \pm 0.10$ & $5.00 \pm 0.10$ & $6.50 \pm 0.10$ \\
& RT & $6.5 \pm 010$ & $5.00 \pm 0.20$ & $6.50 \pm 0.10$ \\
& AT & $6.5 \pm 0.10$ & $5.10 \pm 0.10$ & $6.60 \pm 0.10$ \\
28 & CT & $6.6 \pm 0.10$ & $5.10 \pm 0.20$ & $6.60 \pm 0.10$ \\
& PT & $7.5 \pm 0.10^{\mathrm{b}}$ & $5.80 \pm 0.10^{\mathrm{c}}$ & $6.70 \pm 0.10^{\mathrm{c}}$ \\
& RT & $6.0 \pm 010^{\mathrm{a}}$ & $4.00 \pm 0.20^{\mathrm{b}}$ & $5.50 \pm 0.10^{\mathrm{a}}$ \\
& AT & $6.0 \pm 0.10^{\mathrm{a}}$ & $3.00 \pm 0.10^{\mathrm{a}}$ & $5.00 \pm 0.10^{\mathrm{b}}$ \\
& CT & $7.5 \pm 0.10^{\mathrm{b}}$ & $6.80 \pm 0.20^{\mathrm{d}}$ & $7.30 \pm 0.10^{\mathrm{d}}$ \\
\hline
\end{tabular}

PT (Streptococcus thermophilus + Lactobacillus plantarum). RT (Streptococcus thermophilus + Lactobacillus rhamnosus). AT (Streptococcus thermophilus + Lactobacillus acidophilus). CT (Streptococcus thermophilus + Lactobacillus casei).

cheese, and whether encapsulating the bacteria in alginate microcapsules would increase their survival. Neither free nor encapsulated $L$. paracase $i$ had been affected by incubation in the pancreatinbile solution. The viability determined in different probiotic cheese essays is consistent with the data we have obtained in the research.

\subsection{Sensorial properties}

The inclusion of probiotic bacteria may contribute to distinct flavor and texture characteristics thus changing perceived cheese liking. However, if the sensory properties does not match the costumer expectations, the product will fail in the market. Sensory quality of the food products is considered the most important quality parameter and important in the sense of represent consumer like (Albenzio et al, 2013a). According to Table 5, whereas it was determined that all samples taken too closer sensorial point at first day of storage period, it was seen that in terms of texture scores PT and CT samples pointed equal score (7.5), RT and AT samples pointed equal score (6.5) $(\mathrm{P}<0.05)$ at the end of storage period. Because texture scoring is regarded as the structure when the mass cut off and the similar appearance was occurred, in the scoring big difference didn't occurred. In the consideration any gaps, cracks or holes structure weren't observed. In the consideration that made with regards to taste and aroma, occurred differences in the scoring $(\mathrm{P}<0.05)$, AT has received the lowest score, $\mathrm{RT}$, PT and CT samples followed this, respectively. In this regard, CT sample which $L$. casei culture used in have been seen having as the most suitable taste and aroma. When examined general acceptableness scores a parallel assessment have been made to taste-aroma scores and CT sample took the highest acceptableness and liking score.

Sensory panel showed that the highest average sensory evaluation points were recorded in cheeses made with Streptococcus thermophilus plus Lactobacillus casei, whereas other probiotic bacteria combinations had been effected less in regard to taste or appearance. Previous studies suggest that the inclusion of probiotics does not markedly change the sensory profile of cheese (Albenzio et al, 2013a). Indeed, the use of combined cultures of such as L. acidophilus or other lactic bacteria, particularly in association with Streptococcus thermophilus has been reported as advantageous, due to absence of certain sensory and texture defects and improvement of nutritional value (Buriti et al., 2007b; Gomes da Cruz et al.,
2009). Rodriguez et al. $(1997,1998)$ reported that the use of L. casei subsp. casei in the production of low-fat cheese from ultrafiltered milk resulted in higher levels of FAAs and volatile components in the cheese during ripening and provided the best scores for aroma and flavor development. Ong et al. (2006) studied cheddar cheese and found that cheeses made with the addition of $L$. case $i$ and a mixture of ABC culture (L. acidophilus, $B$. longum, and L. casei) received the lowest acceptance scores. Their results showed that cheddar cheeses made with probiotic adjuncts $B$. longum, B. lactis, and $L$. paracasei or L. acidophilus received acceptance scores comparable with those of control cheese (Karimi et al, 2012b). Several adjunct cultures of strains of the species $L$. casei and L. plantarum have been claimed to increase peptidolysis and improve the sensory properties of cheese (Lynch et al., 1999; Menéndez et al., 2000; Swearingen et al., 2001; Irigoyen et al., 2007). Escobar et al. (2012) reported that probiotic supplementation of Panela Cheese had no effect on perceived taste or appearance and the starchless cheese containing L. rhamnosus GG showed greater consumer acceptance in the compactness, hardness, moisture, and softness descriptors.

\section{Conclusion}

In this study quality properties of the probiotic fresh cheeses produced with S. thermophilus, L. plantarum, L. rhamnosus, $L$. acidophilus and $L$. casei as co-cultures were examined. And in the production of probiotic white cheeses combine using $S$. thermophilus and $L$. casei provides for product more acceptableness in terms of physicochemical and sensory properties. Furthermore in terms of bacterial survival and stability it was seen that this cheese had given better results. In a general sense to evaluate the cheeses produced as a probiotic product, determinating more than 6-7 Log cfu.g ${ }^{-1}$ bacterial viability, which is among the main criteria, is a positive feature. In future studies using different probiotic strains and species in addition to $S$. thermophilus is important for creating different perspectives. Fresh white cheese could be a suitable food for use of probiotic bacteria and manufacturing with high quality and healthy properties.

\section{Acknowledgements}

This research was presented at the "The 2 nd. International Symposium on "Traditional Foods from Adriatic to Caucasus", 24-26 October 2013" as poster proceeding. 


\section{References}

Albenzio, M., Santillo, A., Caroprese, M., Braghieri, A., Sevi, A., \& Napolitano, F. (2013a). Composition and sensory profiling of probiotic Scamorza ewe milk chees. Journal of Dairy Science, 96(5), 2792-2800. PMid:23522674. http://dx.doi.org/10.3168/ jds.2012-6273

Albenzio, M., Santillo, A., Caroprese, M., Ruggieri, D., Napolitano, F., \& Sevi, A. (2013b). Physicochemical properties of Scamorza ewe milk cheese manufactured with different probiotic cultures. Journal of Dairy Science, 96(5), 2781-2791. PMid:23522678. http://dx.doi. org/10.3168/jds.2012-6218

Basyigit Kilic, G., Kuleasan, H., Eralp, I., \& Karahan, A. G. (2009). Manufacture of Turkish Beyaz cheese added with probiotic strains. LWT - Food Science and Technology, 42, 1003-1008. http://dx.doi. org/10.1016/j.lwt.2008.12.015

Bujalance, C., Jiménez-Valera, M., Moreno, E., \& Ruiz-Bravo, A. (2006). A selective differential medium for Lactobacillus plantarum. Journal of Microbiological Methods, 66, 572-575. PMid:16554099. http:// dx.doi.org/10.1016/j.mimet.2006.02.005

Buriti, F. C. A., Cardarelli, H. R., \& Saad, S. M. I. (2007a). Biopreservation by Lactobacillus paracasei in co-culture with Streptococcus thermophilus in potentially probiotic and synbiotic fresh cream-cheeses. Journal of Food Protection, 70, 228-235. PMid:17265887.

Buriti, F. C. A., Okazaki, T. Y., Alegro, J. H. A., \& Saad, S. M. I. (2007b). Effect of a probiotic mixed culture on texture profile and sensory performance of Minas fresh cheese in comparison with the traditional products. Archivos Latinoamericanos de Nutricion, 57, 179-185. PMid:17992983.

Cakmakci, S., Dagdemir, E., Hayaloglu, A. A., Gurses, M., \& Gundogdu, E. (2008). Influence of ripening container on the lactic acid bacteria population in Tulum cheese. World Journal of Microbiology and Biotechnology, 24(3), 293-299. http://dx.doi.org/10.1007/s11274007-9470-Z

Cencic, A., \& Chingwaru, W. (2010). The role of functional foods, nutraceuticals, and food supplements in intestinal health. Nutrients, 2(6), 611-625. PMid:22254045 PMCid:PMC3257668. http://dx.doi. org/10.3390/nu2060611

Dave, R. I., \& Shah, N. P. (1996). Viability of yoghurt and probiotic bacteria in yoghurts made from commercial starter cultures. International Dairy Journal, 7(1), 31-41. http://dx.doi.org/10.1016/ S0958-6946(96)00046-5

Escobar, M. C., Van Tassell, M. L., Martínez-Bustos, F., Singh, M., Casta-o-Tostado, E., Amaya-Llano, S. L., \& Miller, M. J. (2012). Characterization of a Panela and fava bean starch. Journal of Dairy Science, 95(6), 2779-2787. PMid:22612915. http://dx.doi. org/10.3168/jds.2011-4655

Ethiopian Standard Agency - ESA. (2012). ES ISO 6611: milk and milk products: enumeration of colony-forming units of yeasts and/or molds: colony-count technique at $25^{\circ} \mathrm{C}$.

Food and Agriculture Organization of the United Nations - FAO. (2007). Authors Report on Functional Foods, Food Quality and Standards Service (AGNS). Retrieved from http://www.fao.org/ag/ agn/agns/files/Functional_Foods_Report_Nov2007.pdf.

Fooks, L., Fuller, R., \& Gibson, G. R. (1999). Prebiotics-probiotics and human gut microbiology. International Dairy Journal, 9(1), 53-61. http://dx.doi.org/10.1016/S0958-6946(99)00044-8

Gibson, G. R. (2007). Functional foods: probiotics and prebiotics. Culture, 28, 1-8.
Gomes da Cruz, A., Buriti, F. C. A., Batista de Souza, C. H., Fonseca Faria, J. A., Isay Saad, S. M. (2009). Probiotic cheese: health benefits, technological and stability aspects. Trends in Food Science and Technology, 20(8), 344-354. http://dx.doi.org/10.1016/j. tifs.2009.05.001

Gomes, A. A., Braga, S. P., Cruz, A. G., Cadena, R. S., Lollo, P. C. B., Carvalho, C., Amaya-Farfán, J., Faria, J. A. F., \& Bolini, H. M. A. (2011). Effect of the inoculation level of Lactobacillus acidophilus in probiotic cheese on the physicochemical features and sensory performance compared with commercial cheeses. Journal of Dairy Science, 94(10), 4777-4786. PMid:21943729. http://dx.doi. org/10.3168/jds.2011-4175

Grattepanche, F., Miescher-Schwenninger, S., Meile, L., \& Lacroix, C. (2008). Recent developments in cheese cultures with protective and probiotic functionalities. Dairy Science and Technology, 88, 421-444. http://dx.doi.org/10.1051/dst:2008013

Hayaloglu, A. A., Fox, P. F., Guven, M., \& Cakmakci, S. (2007). Cheeses of Turkey: 1. Varieties ripened in goat-skin bags. Lait, 87(2), 79-95. http://dx.doi.org/10.1051/lait:2007006

Hayaloglu, A. A., Guven, M., Fox, P. F. (2002). Micro\#biological, biochemical and technological properties of Turkish White cheese “Beyaz Peynir". International Dairy Journal, 12(8), 635-648. http:// dx.doi.org/10.1016/S0958-6946(02)00055-9

International Organization for Standardization - ISO. (2006). ISO 4831: microbiology of food and animal feeding stuffs: horizontal method for the detection and enumeration of coliforms: most probable number technique.

Irigoyen, A., Ortigosa, M., Juansaras, I., Oneca, M., \& Torre, P. (2007). Influence of an adjunct culture of Lactobacillus on the free amino acids and volatile compounds in a Roncal-type ewe's-milk cheese. Food Chemistry, 100(1), 71-80. http://dx.doi.org/10.1016/j. foodchem.2005.09.011

Jordano, R., Serrano, C. E., Torres, M., \& Salmeron, J. (1992). Comparison of three M17 media for the enumeration of Streptococcus thermophilus in fermented dairy products. Journal of Food Protection, 55, 999-1000.

Kahraman, O., \& Ustunol, Z. (2012). Effect of zinc fortification on Cheddar cheese quality. Journal of Dairy Science, 95(6), 2840-2847. PMid:22612921. http://dx.doi.org/10.3168/jds.2011-4945

Karimi, R., Mortazavian, A. M., \& Karimi, M. (2012a). Incorporation of Lactobacillus casei in Iranian ultrafiltered Feta cheese made by partial replacement of $\mathrm{NaCl}$ with $\mathrm{KCl}$. Journal of Dairy Science, 95(8), 4209-4222. PMid:22818434. http://dx.doi.org/10.3168/ jds.2011-4872

Karimi, R., Sohrabvandi, S., \& Mortazavian, A. M. (2012b). Review Article: sensory characteristics of probiotic cheese. Comprehensive Reviews in Food Science and Food Safety, 11(5), 437-452. http:// dx.doi.org/10.1111/j.1541-4337.2012.00194.x

Lollo, P. C. B., Cruz, A. G., Morato, P. N., Moura, C. S., CarvalhoSilva, L., Oliveira, C. A. F., Faria, J. A. F., \& Amaya-Fartan, J. (2012). Probiotic cheese attenuates exercise-induced immune suppression in Wistar rats. Journal of Dairy Science, 5(7), 3549-3558. PMid:22720913. http://dx.doi.org/10.3168/jds.2011-5124

Lynch, C. M., Muir, D. D., Banks, J. M., Mcsweeney, P. L. H., \& Fox, P. F. (1999). Influence of adjunct cultures of Lactobacillus paracasei ssp. paracasei or Lactobacillus plantarum on Cheddar cheese ripening. Journal of Dairy Science, 82(8), 1618-1628. http://dx.doi. org/10.3168/jds.S0022-0302(99)75390-7

Magdoub, M. N. I., Osman, S. H. G., \& El-Kenawy, M. M. (2005). Effect of different starter cultures on composition and microbiological 
quality of Ain shams cheese. Egyptian Journal of Applied Science, 10, 132-141.

Menéndez, S., Centeno, J. A., Godínez, R., \& Rodríguez-Otero, J. L. (2000). Effect of Lactobacillus strains on the ripening and organoleptic characteristics of Arzua-Ulloa cheese. International Journal of Food Microbiology, 59(1-2), 37-46. http://dx.doi. org/10.1016/S0168-1605(00)00286-5

Minervini, F., Siragusa, S., Faccia, M., Dal Bello, F., Gobbetti, M., \& De Angelis, M. (2012). Manufacture of Fior di Latte cheese by incorporation of probiotic lactobacilli. Journal of Dairy Science, 95(2), 508-520. PMid:22281315. http://dx.doi.org/10.3168/jds.20114150

Oner, Z., Karahan, A. G., \& Aloglu, H. (2006). Changes in the microbiological and chemical characteristics of an artisanal turkish white cheese during ripening. LWT - Food Science and Technology, 39(5), 449-454. http://dx.doi.org/10.1016/j.lwt.2005.03.015

Ong, L., Henriksson, A., \& Shah, N. P. (2006). Development of probiotic Cheddar cheese containing Lb. acidophilus, Lb. paracasei, Lb. casei and Bifidobacterium spp. and the influence of these bacteria on proteolytic patterns and production of organic acid. International Dairy Journal, 16(5), 446-456. http://dx.doi.org/10.1016/j. idairyj.2005.05.008

Ortakci, F., Broadbent, J. R., Mcmanus, W. R., \& Mchahon, D. J. (2012). Survival of microencapsulated probiotic Lactobacillus paracasei LBC-1e during manufacture of Mozzarella cheese and simulated gastric digestion. Journal of Dairy Science, 95(11), 6274-6281. PMid:22981567. http://dx.doi.org/10.3168/jds.2012-5476

Rodriguez, J., Requena, T., \& Juarez, M. (1998). Process for low-fat cheese from ultrafiltered milk. Journal of Food Science, 63(4), 665667. http://dx.doi.org/10.1111/j.1365-2621.1998.tb15808.x

Rodriguez, J., Requena, T., Valero, E., Martínez Castro, I., López Fandiño, R., \& Juárez, M. (1997). Proteolysis and volatile components of reduced-fat cheeses made from ultrafiltered milk and different starters supplemented with lactobacilli and Lac-Prtlactococci. Lait, 77, 717-728. http://dx.doi.org/10.1051/lait:1997651

Stanton, C., Gardiner, G., Lynch, P. B., Collins, J. K., Fitzgerald, G., \& Ross, R. P. (1998). Probiotic cheese. Interntional Dairy Journal, 8(5-6), 491-496. http://dx.doi.org/10.1016/S0958-6946(98)00080-6

Swearingen, P. A., O'Sullivan, D. J., \& Warthesen, J. J. (2001). Isolation, characterization, and influence of native, nonstarter lactic acid bacteria on Cheddar cheese quality. Journal of Dairy Science, 84(1), 50-59. http://dx.doi.org/10.3168/jds.S0022-0302(01)74451-7

Tabasco, R., Paarup, T., Janer, C., Peláez, C., \& Requena, T. (2007). Selective enumeration and identification of mixed cultures of Streptococcus thermophilus, Lactobacillus delbrueckii subsp. bulgaricus, L. acidophilus, L. paracasei subsp. paracasei and Bifidobacterium lactis in fermented milk. International Dairy Journal, 17(9), 1107-1114. http://dx.doi.org/10.1016/j.idairyj.2007.01.010

Tharmaraj, N., \& Shah, N. P. (2003). Selective enumeration of Lactobacillus delbrueckii spp. bulgaricus spp, Streptococcus thermophilus, Lactobacillus acidophilus, bifidobacteria, Lactobacillus casei, Lactobacillus rhamnosus and Propinibacteria. Journal of Dairy Science, 86(7), 2288-2296. http://dx.doi.org/10.3168/jds.S00220302(03)73821-1

Tuncer, Y. (2009). Some Technological Properties of Phenotypically Identified Enterococci Strains Isolated from Turkish Tulum Cheese. African Journal of Biotechnology, 8, 7008-7016.

Turkey, Ministry of Agriculture and Rural Affairs. (2000). Turkish Food Codex Communiqué on Raw Milk and Heat Treated Drinking Milk. (Communiqué No. 2000/6).

Turkish Standard (2006). Turkish White Cheese Standard (TS-591). Ankara.

Vinderola, C. G., Prosello, V., Ghiberto, D., \& Reinheimer, J. A. (2000). Viability of Probiotic (Bifidobacterium, Lactobacillus acidophilus and Lactobacillus casei) and Nonprobiotic Microflora in Argentinian Fresco Cheese. Journal of Dairy Science, 83(9), 1905-1911. http:// dx.doi.org/10.3168/jds.S0022-0302(00)75065-X 